\title{
IMPLEMENTATION OF MULTI-PROFESSIONAL EDUCATION: A SHORT REVIEW OF THE RESEARCH METHODOLOGY AND BIOSTATISTICS COURSE
}

\author{
Herry Novrinda ${ }^{1 *}$ \\ ${ }^{1}$ Department of Dental Public Health and Preventive Dentistry, Universitas Indonesia, Jakarta - INDONESIA \\ Submitted: 25 Nov 2020; Final Revision from Authors: 08 Mar 2021; Accepted: 16 Mar 2021
}

\begin{abstract}
Background: The faculty of Dentistry Universitas Indonesia (FDUI) has implemented multiprofessional education (MPE) since the academic year of 2012/2013. Some concerns about facilitators and the achievement of students arose. This study aims (1) to describe the curriculum mapping, (2) to elaborate the perception of facilitators regarding the implementation of MPE, and (3) to assess the achievement among non-MPE and MPE groups in a particular subject.
\end{abstract}

Methods: This research used a quantitative and qualitative approach. This research collected the data of achievement, perception of facilitators, and the curriculum in order to assess the implementation of MPE.

Results: The curriculum consisted of common subjects or topics. There were some suggestions regarding the facilitators and the curriculum in the implementation of MPE. In line with one-way Annova, the mean score of students among Non-

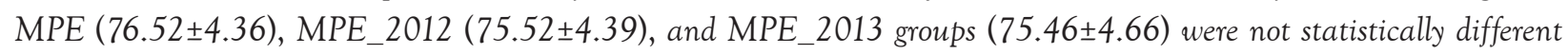
with p-value $=0.154$.

Conclusion: The faculty has succeeded in compiling an integrated MPE curriculum. There are opportunities for an improvement in several areas. The academic achievement of MPE students is as good as Non-MPE students. The MPE group's research proposals seemed to have a spirit of collaboration.

Keywords: multiprofessional, education, dental, assessment, qualitative, quantitative

\section{PRACTICE POINTS}

- Multiprofessional education is successful to maintain students' achievement.

- Multiprofessional education encouraged the spirit of collaboration.

- The curriculum and the facilitators have the opportunities for improvement.

\section{INTRODUCTION}

One of the visions of the Faculty of Dentistry Universitas Indonesia (FDUI) is to become the leading Faculty of Dentistry in the field of education, research, and community service with integration and autonomy as its development strategy. ${ }^{1}$ To achieve these goals, since 2003, FDUI organized academic education by way of active learning using many approaches such as problem-based learning (PBL), collaborative learning (CoL), questions-based learning

*corresponding author, contact: herry_n@ui.ac.id 
(QBL), and others which emphasize student-centered learning that are effective, including students from $\geq 2$ disciplines working together. ${ }^{2}$ Besides that, since the academic year of 2012/2013, FDUI has implemented interprofessional/multiprofessional education (IPE/ MPE).

Interprofessional education (IPE) is defined as "those occasions when students of two or more health care professions learn with, from, and about one another to improve collaboration and the quality of care" (WHO). ${ }^{3}$ MPE is defined as "the process by which a group of students in health related fields and with different educational backgrounds are learning together during certain periods of their education" (WHO). ${ }^{4}$ There are various perspectives regarding the difference of IPE and MPE. Roodbol mentioned that the concept of MPE features interactive learning as part of interprofessional learning. The difference between IPE and MPE is only in terms of numbers. Interprofessional has two professions while multi professionals have more than two professions. ${ }^{5}$ However, some efforts were proposed to distinguish between IPE and MPE "more substantive" than just number. Goldman et al through a sociological approach, mentioned that IPE and MPE represent different educational processes. ${ }^{6}$ Barr et al defined " $a$ multiprofessional course when members (or students) of two or more professions learn alongside one another: in other words, parallel rather than interactive learning". They stated that the difference between the two lies in the parallel educational process. ${ }^{7}$ Adiatman concluded that IPE as "two or more professions learn from and about each other (not learn with), to improve collaboration and health care services while MPE is two or more professions learn together, for various purposes".

The learning process of The Research Methodology \& Biostatistics (RMB) course was conducted simultaneously/parallel with five professions alongside one another. Many resources (modules, facilitators, discussion rooms, and other facilities) were utilized at the same time. Hence, the terminology of MPE is used in this study. Health Science Cluster (Rumpun Ilmu Kesehatan) in Universitas Indonesia had proposed an integrated interprofessional curriculum for several subjects in collaboration with five faculties (Medicine, Dentistry, Public Health,
Nursing, and Pharmacy). These subjects are Basic Biomedical Sciences, Ethics $\mathcal{E}$ Law in Health Profession, Health Team Collaboration, Effective Communication in Healthcare Services, Disaster Management, Research Methodology $\mathbb{E}$ Biostatistics. ${ }^{8}$ This curriculum has been implemented since 2013. Therefore, an evaluation or assessment should be conducted in order to improve and maintain the sustainability of this program. There is no evaluation that has been done, whether by comparing with Non-IPE or comparing all IPE batch years.

At the level of preparation and implementation, it is undeniable that there are some concerns regarding MPE. This study aims: (1) to describe the curriculum mapping of FDUI, (2) to elaborate the perception of facilitators about the implementation of MPE, and (3) to assess the achievement among MPE and non-MPE group students (three academic years) in a particular subject. The hypothesis is the achievement of MPE-students would be as good as Non-MPE students.

\section{METHODS}

A study that focuses on collecting, analyzing, and mixing both quantitative and qualitative data is commonly defined as a mixed method. ${ }^{9}$ This study used a quantitative and qualitative data to assess the implementation of MPE.

The quantitative data which consist of data regarding grades of undergraduate students $(\mathrm{N}=311)$ were collected from FDUI administration office (for NonMPE students) and official data from UI academic system information (for MPE students). Non-MPE students were from batch year $2010(n=107)$ and MPE students were from batch year $2012(n=95)$ and $2013(\mathrm{n}=109)$. All students who learned this course in their $4^{\text {th }}$ semester (batch 2010 in the year 2012; batch 2012 in 2014; and batch 2013 in the year 2015).

The qualitative data which consist of Information regarding the perception of facilitators $(n=41$ from 5 faculties) was reviewed from the final report of The RMB module team in 2015. Whereas the information on curriculum mapping was collected from FDUI administration office. The Document review is one of strategy in qualitative approach ${ }^{10,11}$ and one of the eligible documents is organizational or institutional 
reports or summaries. ${ }^{11}$ The data from many resources (such as documents) are then organized into major themes, categories, and case examples through content analysis. ${ }^{12}$ The analytic procedure encompasses the process of finding, selecting, apprising (to make sense of), and synthesising data included in documents. ${ }^{11}$

At the end of the semester, all facilitators were asked to provide opinions and suggestions through a set of open-ended questionnaires on several issues related to the learning of this course. The opinions and suggestions of the facilitators were grouped into the major themes asked in the questionnaire. ${ }^{11,12}$ The grouping was based on the scope of implementation which include the curriculum, team teaching, supporting staff, and learning facility. The RMB course was selected in this study with the following considerations:

1. The course had been included in FDUI curriculum before MPE implementation;

2. The availability and accessibility of the data (before and after MPE).

The quantitative data regarding the achievement of students were analyzed statistically with One-Way ANOVA using SPSS 23.
This study used secondary data that is not related to informed consent and does not use body or body parts/specimens, therefore only requires permission to use the data which permission has been obtained from related parties.

\section{RESULTS AND DISCUSSION}

There were two stages of an undergraduate program at FDUI:

1) Academic Stage (Bachelor of Dental Science) and

2) Professional/Clinical Stage (DDS).

In the academic stage curriculum, there were three main components: the subject encompasses Mandatory Courses from University, Mandatory Courses from Health Science Major (Interprofessional Education), Mandatory Courses from Dental Science Major. In this study, the academic stage, especially the RMB course, would be explored.

Referring to the definition of IPE/MPE, ${ }^{3,13}$ the Universitas Indonesia MPE preparation team is required to compile common subjects/topics among five faculties. Based on the team's recommendations, FDUI then compiled a curriculum as shown in Table 1 .

Table 1. Three Domain Subjects for Academic Stage Curriculum and Credit In FDUI

\begin{tabular}{|c|c|c|c|}
\hline No. & Subject & $\begin{array}{l}\text { No of } \\
\text { Credit }\end{array}$ & $\begin{array}{l}\text { \% Credit Compare to } \\
\text { Total Credit }\end{array}$ \\
\hline 1. & $\begin{array}{l}\text { Mandatory Subjects from University (Civic Subject, } \\
\text { Religion, English for academic purposes, art } \& \text { sports, } \\
\text { Liberal Art) }\end{array}$ & 18 & 12.50 \\
\hline 2. & $\begin{array}{l}\text { Mandatory Subjects from Health Sciences Major (Inter/ } \\
\text { Multi-Professional Education) encompass: } \\
\text { a. Ethics } \mathcal{E} \text { Law in Health Profession } \\
\text { b. Basic Biomedical Sciences } \\
\text { c. Health Team Collaboration } \\
\text { d. Effective Communication in Healthcare Services } \\
\text { e. Disaster Management } \\
\text { f. Research Methodology } \mathbb{E} \text { Biostatistics }\end{array}$ & $\begin{array}{r}15 \\
2 \\
4 \\
2 \\
2 \\
2 \\
3\end{array}$ & 10.42 \\
\hline 3. & $\begin{array}{l}\text { Mandatory Subjects from Dental Sciences Major } \\
\text { (including research-based undergraduate thesis) }\end{array}$ & 111 & 77.08 \\
\hline & Total & 144 & 100 \\
\hline
\end{tabular}


From Table 1, we could see the result of curriculum mapping. "The curriculum mapping is a systematic process used to create an inventory of what is being been taught, learning outcomes, pedagogic methods, time allotted to identified concepts and assessment strategies." 14 The UI-MPE team had successfully identified common subjects or topics (including subtopics) for five different health professions. The six subjects represented competencies that should be included in the curriculum. The core competencies were values, ethics and law, communication, collaboration, ${ }^{14}$ basic biomedical sciences, and research methodology and biostatistics. ${ }^{8}$ The six subjects were similar with a curriculum mapping by Langlois et al regarding topics and sub-topics for eleven health profession programs at the University of Toronto. ${ }^{14}$

Faculty of Dentistry Universitas Indonesia as a part of the Health Science Cluster had collaborated for 15 credits (10.42\%). It was a quiet achievement considering the complexity of problem ${ }^{15}$ either to gather five different health professions or internal dynamics in the faculty. From the six common topics identified, four of them were included in the FDUI curriculum before the implementation of MPE. The common topics were ethics and law, communication, basic biomedical sciences, and research methodology and biostatistics. Furthermore, several concerns regarding the students' achievement were raised. "How can they learn "our content" with facilitators and friends from other faculties?" or "how do we ensure that students' achievement will not be different while they learn with facilitators and friends from different faculties?"

There were several suggestions on the implementation of MPE in FDUI. After three years of implementation (2012-2015), several parties involved in the policy-making process as well as those involved in the implementation stage including the facilitators addressed their comments related to the implementation of MPE. The assessment of the implementation of MPE encompassed curriculum (modules and teaching materials), team teaching (team modules, resource persons, and facilitators), administrative personnel, and supporting facilities. The concerns about achievement (score) as previously mentioned will be discussed with the support of objective analysis.

Table 2. The scope of Suggestions to Revise the MPE Implementation

\begin{tabular}{|c|c|c|c|c|}
\hline No. & $\begin{array}{c}\text { Scope of } \\
\text { Implementation }\end{array}$ & $\begin{array}{l}\text { Scope of } \\
\text { Evaluation }\end{array}$ & Planned Condition & Suggestion \\
\hline 1. & Curriculum & $\begin{array}{l}\text { Modules and } \\
\text { Teaching } \\
\text { Materials }\end{array}$ & $\begin{array}{l}\text { Available in hardcopy and } \\
\text { softcopy and uploaded in } \\
\text { SCeLE ( known as EMAS: } \\
\text { emas2.ui.ac.id) }\end{array}$ & $\begin{array}{l}\text { Modules should be revised with "up to } \\
\text { date" contents and references. }\end{array}$ \\
\hline 2. & \multirow[t]{2}{*}{ Team Teaching } & Team's Module & $\begin{array}{l}\text { Representativeness of the } \\
\text { faculties: Expert in the } \\
\text { RMB subject }\end{array}$ & $\begin{array}{l}\text { - If it is possible, Members of the } \\
\text { module team from each faculty } \\
\text { should be rotated with other lecturers } \\
\text { from the same faculty at least once } \\
\text { every } 2 \text { or three years. } \\
\text { - This is a suggestion from team's } \\
\text { module. }{ }^{16} \text { The team's module should } \\
\text { have better coordination with the } \\
\text { facilitators, among team members, } \\
\text { and resource persons. }\end{array}$ \\
\hline & & Resource Persons & Available & $\begin{array}{l}\text { - Sometimes, the resource persons } \\
\text { could not attend to their scheduled } \\
\text { session so team members should } \\
\text { substitute them. } \\
\text { - The honorarium for resource persons } \\
\text { might not be worth their expertise. }{ }^{16}\end{array}$ \\
\hline
\end{tabular}




\begin{tabular}{|c|c|c|c|c|}
\hline & & Facilitators & $\begin{array}{l}\text { - Available for all classes. } \\
\text { - The performance of the } \\
\text { facilitator was usually } \\
\text { assessed by his/her } \\
\text { student at the end of } \\
\text { semester through an } \\
\text { internet-based evaluation } \\
\text { system (www.edom.ui.ac. } \\
\text { id). }\end{array}$ & $\begin{array}{l}\text { - Some facilitators were late for their } \\
\text { class. } \\
\text { - Some facilitators were unable to } \\
\text { attend the class and did not inform } \\
\text { in advance. The team module had } \\
\text { difficulty finding replacements. } \\
\text { - Sometimes some facilitators did not } \\
\text { know for sure the learning issues on } \\
\text { that day so they were confused about } \\
\text { facilitating their class. } \\
\text { - Facilitators should assess their } \\
\text { student's discussion and input it into } \\
\text { SCeLE (now known as EMAS). Many } \\
\text { facilitators did not input into SCeLE } \\
\text { so that it was difficult for them to } \\
\text { calculate the final score. } \\
\text { - Apart from the students, facilitators } \\
\text { should also be evaluated /assessed by } \\
\text { their fellow facilitators and the team's } \\
\text { module. }\end{array}$ \\
\hline \multirow[t]{2}{*}{3.} & \multirow[t]{2}{*}{ Supporting Staff } & $\begin{array}{l}\text { Administration } \\
\& \text { Laboratory } \\
\text { Personnel }\end{array}$ & $\begin{array}{l}\text { Always on standby before } \\
\text { and after a session. }\end{array}$ & $\begin{array}{l}\text { They have completed their task and } \\
\text { the faculty was advised to increase } \\
\text { their incentives considering in special } \\
\text { circumstances, they were also standby in } \\
\text { the Laboratory. }\end{array}$ \\
\hline & & $\begin{array}{l}\text { Room } \\
\text { Personnel/ } \\
\text { Cleaning Service }\end{array}$ & $\begin{array}{l}\text { Always on standby before, } \\
\text { during, and after session. }\end{array}$ & $\begin{array}{l}\text { They have completed their task and the } \\
\text { faculty was advised to give reward for } \\
\text { their assistance. }\end{array}$ \\
\hline & \multirow{3}{*}{$\begin{array}{l}\text { Infrastructure } \\
\text { and Facilities }\end{array}$} & $\begin{array}{l}\text { Discussion and } \\
\text { Seminar Room }\end{array}$ & $\begin{array}{l}\text { The required rooms were } \\
\text { available on schedule. } \\
\text { A number of discussion } \\
\text { rooms (each for about } 20 \\
\text { students) and seminar } \\
\text { rooms (each for } 200 \\
\text { students) were available. }\end{array}$ & $\begin{array}{l}\text { The rooms with capacity for } 50-100 \\
\text { people should be provided. }\end{array}$ \\
\hline & & Laboratory & $\begin{array}{l}\text { The required rooms were } \\
\text { available on schedule. }\end{array}$ & $\begin{array}{l}\text { The several of other equipment should } \\
\text { be provided }\end{array}$ \\
\hline & & $\begin{array}{l}\text { Audio Visual } \\
\text { Aid }\end{array}$ & $\begin{array}{l}\text { The required AVAs were } \\
\text { available on schedule. }\end{array}$ & $\begin{array}{l}\text { There were any AVAs that could not be } \\
\text { used/broken. They must be repaired or } \\
\text { replaced. }\end{array}$ \\
\hline
\end{tabular}

Table 2 shows that the themes of suggestions are mainly facilitators and content/curriculum. It means these "areas" should be in our priority. These findings highlight a number of challenges to IPE/MPE, such as cultural changes, curriculum, timetable, and sustainability. ${ }^{17}$ In addition, there are also financial issues regarding the reward/honorarium for resource persons and supporting staffs. It is a common issue when implementing the MPE. West et al mentioned such challenges when carrying out IPE activities, including scheduling, logistics, and financial support. ${ }^{18}$

Facilitator is one of the main concerns because their role in the learning process is one of the key factors in an active learning process. ${ }^{19}$ Their competence and behavior should be assessed beforehand in order to improve their performance and decide which group should they be assigned to, either for team module or faculty. Due to its interactive and 
constructivist, MPE requires special facilitation skills to engage students in learning from each other. ${ }^{18}$ The Interprofessional Facilitation Scale (IPFS) is one of the tools to assess skills in facilitating MPE. Sargent et al has confirmed its validity and reliability. ${ }^{20}$ In addition to skills assessment, a follow-up is deemed to improve facilitators' capacity building as Davis et al concluded in their study. ${ }^{21}$

As a response regarding students' achievement in MPE courses, a set of student's scores on the RMB course was analyzed by comparing the scores of non-MPE students, MPE students batch 2012, and MPE students batch 2013. Table 3 shows the scores (minimum and maximum) among the three groups are quite similar. Based on the UI grading categories, all the mean scores are in category $\mathrm{B}+(75-79) .{ }^{16}$ Test homogeneity of variance showed that $p$ value was $0.951(>0.05)$ and ANOVA test was eligible to be performed.

Table 3. Students' Score from Non-MPE and MPE Groups*

\begin{tabular}{lrcc}
\multicolumn{1}{c}{ Groups } & \multicolumn{1}{c}{ N } & Mean \pm SD & $\mathbf{p}^{*}$ \\
Non MPE_2010 & 107 & $76.52 \pm 4.36$ & \\
MPE_2012 & 95 & $75.52 \pm 4.39$ & 0.154 \\
MPE_2013 & 109 & $75.46 \pm 4.66$ & \\
\hline
\end{tabular}

*obtained from One-way ANOVA

From the table above, it can be concluded that the student's achievement between non-MPE and MPE is not different. The concern regarding students' achievement had been responded to. This kind of analysis is ideally conducted for all courses so that a comprehensive conclusion could be established. As typology for outcomes of interprofessional learning process, acquisition of knowledge/skills is only a level of outcomes. ${ }^{22}$ There were still many outcomes that should be assessed with qualified measuring instruments. ${ }^{22,23}$

An interesting finding from MPE student groups was their research proposals. The MPE group's research proposals seemed to have a "more collaborative" theme than the non-MPE. A number of proposals either explicitly or implicitly had planned to conduct oral health research with other health professions collaboratively. This phenomenon might be noticed as an achievement even though it was not planned or included in the assessment. It might be reflection of MPE values/competencies as suggested by Steven et al. ${ }^{24}$ This is likely triggered by the learning process of the RMB course which brings together students from 5 faculties and learn together in one group. A study in Korea inferred that exposure to collaboration situations through interprofessional education leads to a positive perception of interprofessional learning. ${ }^{25}$ The disclosure of this unpredictable positive phenomenon is one of the advantages of the qualitative method. ${ }^{26}$

These overarching findings should be interpreted in light of their limitations. First, the available data was limited to the range from batch 2010 to 2013. In addition, only the RMB score was assigned as the reference for student achievement. Second, the scope of assessment was limited to several aspects. Apart from its limitations, this study has several strengths including the use of a mixed approach that allows the disclosure of more comprehensive findings. In addition, this study has revealed important aspects that need attention in the implementation of MPE so that it might be appropriate as a reference for other (dental) schools.

\section{CONCLUSION}

The faculty team has succeeded in compiling an integrated MPE curriculum. There are opportunities for improvement in several areas especially for facilitators and curriculum. The academic achievement of MPE students is as good as Non MPE students. The MPE group's research proposals seemed to have a spirit of collaboration.

\section{RECOMMENDATION}

A number of follow-up studies for students from batch 2010, 2012, and 2013 should be conducted in order to gather a more comprehensive assessment of MPE. Several improvements should be addressed for better MPE implementation as well as assessment either for facilitators or students. 


\section{ACKNOWLEDGEMENTS}

The author expresses the gratitude and appreciation to Prof. Han Dong Hun, DDS, MSD, PhD (Seoul National University) and Melissa Adiatman, DDS, $\mathrm{PhD}$ (Universitas Indonesia) for their support and suggestions. Dr. Engkus Kusdinar as the coordinator of the module team who granted the permission to use their report and all parties (leaders of the FDUI, members of module teams, facilitators, students, administrative officers and others) who have contributed directly or indirectly to this study.

\section{CONFLICT OF INTEREST}

The authors declare that there are no competing interests related to this study.

\section{LIST OF ABBREVIATIONS}

FDUI : Faculty of Dentistry Universitas Indonesia IPE : Interprofessional education

MPE : Multiprofessional education

RMB : The Research Methodology \& Biostatistics

PBL : Problem Based Learning

CoL : Collaborative Learning

QBL : Question Based Learning

SCeLE: Student Center E-Learning Environment (scele.ui.ac.id)

EMAS : E-Learning Management System (emas2. ui.ac.id)

\section{AUTHORS' CONTRIBUTION}

Herry Novrinda - developing research conceptualization, collecting data, data analysis, writing and publication manuscript.

\section{REFERENCES}

1. FKG_UI Visi dan Misi FKG UI. Jakarta. "www. fkg.ui.ac.id/ikhtisar". 2016.

2. D'Eon M. A blueprint for interprofessional learning. J Interprof Care 2005;19 Suppl 1:49-59.

3. Framework for action on interprofessional education and collaborative practice. Geneva: World Health Organization; 2010.

4. Personnel WSGoMEoH. Learning Together to Work Together for Health: Report of a WHO Study Group on Multiprofessional Education of
Health Personnel: the Team Approach: World Health Organization; 1988.

5. Roodbol PF. Multiprofessional education to stimulate collaboration: a circular argument and its consequences. Tijdschrift voor Medisch Onderwijs 2010;29(1):61-65.

6. Goldman J, Kuper A, Whitehead C, et al. Interprofessional and multiprofessional approaches in quality improvement education. Adv Health Sci Educ Theory Pract 2020.

7. Barr H, Ford J, Gray R, et al. Interprofessional Education Guidelines 2017: CAIPE United Kingdom; 2017.

8. Adiatman M. From Inter-professional Education (IPE) to Inter-collaborative Practice : UI Experience. Tokyo; 2016.

9. Tariq S, Woodman J. Using mixed methods in health research. JRSM short reports 2013;4(6):2042533313479197.

10. Bretschneider PJ, Cirilli S, Jones T, Lynch S, Wilson NA. Document review as a qualitative research data collection method for teacher research: SAGE Publications Ltd; 2017.

11. Bowen GA. Document analysis as a qualitative research method. Qualitative research journal 2009.

12. Labuschagne A. Qualitative research: Airy fairy or fundamental. The qualitative report 2003;8(1):100-03.

13. Dallaghan GLB, Lyden E, Meza J, et al. The Nebraska Interprofessional Education Attitudes Scale: a new instrument for assessing the attitudes of health professions students. Journal of Interprofessional Education \& Practice 2016;4:33-39.

14. Langlois S. Mapping current health professional curricula: Identifying common topics for an integrated interprofessional education curriculum. Journal of Interprofessional Education \& Practice 2016;5:7-9.

15. O'Keefe M, Ward H. Implementing interprofessional learning curriculum: how problems might also be answers. BMC Med Educ 2018;18(1):132.

16. Ahmad K, Ernawati B, Gayatri D, Andrajati R, Novrinda H. Laporan Tim Metodologi Penelitian RIK UI; 2015. 
17. Teodorczuk A, Khoo TK, Morrissey S, Rogers G. Developing interprofessional education: putting theory into practice. The clinical teacher 2016;13(1):7-12.

18. West C, Graham L, Palmer RT, et al. Implementation of interprofessional education (IPE) in 16 US medical schools: Common practices, barriers and facilitators. Journal of Interprofessional Education \& Practice 2016;4:41-49.

19. Couto LB, Bestetti RB, Restini CB, Faria M, Jr., Romao GS. Brazilian medical students' perceptions of expert versus non-expert facilitators in a (non) problem-based learning environment. Med Educ Online 2015;20:26893.

20. Sargeant J, Hill T, Breau L. Development and testing of a scale to assess interprofessional education (IPE) faciliation skills. Journal of Continuing Education in the Health Professions 2010;30(2):126-31.

21. Davis BP, Clevenger CK, Posnock S, Robertson BD, Ander DS. Teaching the teachers: faculty development in inter-professional education. Appl Nurs Res 2015;28(1):31-5.
22. Barr H, Freeth D, Hammick M, Koppel I, Reeves S. Evaluations of interprofessional education: a United Kingdom review for health and social care. 2000.

23. Oates M, Davidson M. A critical appraisal of instruments to measure outcomes of interprofessional education. Medical Education 2015;49(4):386-98.

24. Steven K, Howden S, Mires G, et al. Toward interprofessional learning and education: Mapping common outcomes for prequalifying healthcare professional programs in the United Kingdom. Medical Teacher 2017;39(7):720-44.

25. Yu J, Lee w, Kim M, et al. Effectiveness of simulation-based interprofessional education for medical and nursing students in South Korea: a pre-post survey. BMC Medical Education 2020;20(1):476.

26. McGuire LE, StewartAL, Akerson EK, Gloeckner JW. Developing an integrated interprofessional identity for collaborative practice: Qualitative evaluation of an undergraduate IPE course. Journal of Interprofessional Education \& Practice 2020;20:100350. 